\title{
Green, brown or grey: green roofs as 'sustainable' infrastructure
}

\author{
J. Rogers \\ RMIT University, Australia
}

\begin{abstract}
Green roofs, along with vertical gardens are increasingly seen as the symbol Sassi (Strategies for Sustainable Architecture 2006) or epithet Weiler and Scholz-Barth (Green Roof Systems: A Guide to the Planning, Design, and Construction of Landscapes over Structure 2009) of 'green' and 'sustainable cities' because of the ecosystem services that they provide Beatley (Green Cities of Europe: Global Lessons on Green Urbanism 2012). The list of benefits attributed to green roofs is broad and widely shared. They include reduction in the heat island effect, noise reduction, energy conservation, amenity, replacement of lost green space where 'the footprint of a building is replaced with a green roof, with no net loss of green open space or habitat' Hopkins and Goodwin (Living Architecture: Green Roofs and Walls 2011), increased property values, storm water management along with what has been described as 'green relief' in highly dense cities. Green roofs it is further claimed to 'transform cities from urban grey to urban green' (Weiler and Scholz-Barth, 2009) while at the same time mitigating the effects of climate change.

The paper is based on an evaluation of five green roofs in the city of Melbourne, Australia that analyzes to what extent these projects meet the claimed sustainability benefits. It poses the question are green roofs simply 'green' branding or does their construction provide tangible 'sustainability' outcomes and if so what and for whom.

Keywords: sustainability, sustainable cities, green roofs, brown roofs, public space, access and equity.
\end{abstract}




\section{Introduction}

Green Roofs, along with vertical gardens are increasingly seen as the symbol (Sassi [1]) or epithet (Weiler and Scholz-Barth [2]) of 'green' and 'sustainable cities' because of the ecosystem services that they provide (Beatley [3]). They are also often seen as the antidote to the impacts of the compact, dense city: a spatial layout that is well established in sustainable city discourse. This paper poses the question are green roofs simply 'green' branding or does their construction provide tangible 'sustainability' outcomes and if so how have they been, and how could they be measured across the three poles of sustainability environmental, economic and social? In the literature there is an overriding emphasis on defining green roofs in terms of colour - green, brown or grey -that works to silence the critic - because, after all, who would choose grey?

The paper begins with an exploration of how the terms 'green' and sustainable' are deployed in discussions about the benefits of green roofs internationally because the meaning of these terms is far from being self-evident. It then turns to a discussion of what could be considered the 'darker' less 'friendly' side of the case for green roofs where green roofs are seen as a replacement for other 'green spaces' in cities or as Davis [5] puts it the 'architectural privatization' of democratic public space, and considers some of the implications of this within a sustainability framework. The paper concludes with a brief case study of five green roofs in the city of Melbourne. The discussion forms part of a larger study that evaluated the projects according to sustainability criteria drawn from existing literature on the benefits of green roofs. The focus in this paper is principally on access and design intent. While there is some evidence of reduction in energy use and storm water flows in the rooftops studied the social benefits are limited to those who currently occupy the buildings.

Before beginning however it is important to consider the question what is a green roof? Discussions about what they are - or put more simply - what is 'green' about green roofs - suffer from being muddled, muddied, vague and often contradictory.

\section{What is a green roof?}

Along with green walls, rain gardens, street trees and permeable paving, green roofs are part of an emerging global discourse around greener cities. 'Green roof' is an umbrella terms used to describe a number of systems for green rooftops of buildings. The list of benefits attributed to green roofs is broad and widely shared. They include reduction in the heat island effect, noise reduction, energy conservation, amenity, replacement of lost green space, where 'the footprint of a building is replaced with a green roof, with no net loss of green open space or habitat' (Hopkins and Goodwin [4]) increased property values, storm water management along with what has been described as 'green relief' in highly dense cities. Green roofs, it is further claimed, 'transform cities from urban grey to 
urban green' (Weiler and Scholz-Barth [2]) while at the same time mitigating the effects of climate change.

Green roofs can be either extensive or intensive, depending on the load bearing potential of the building, depth of soil, maintenance required, access and the aims of the project. Extensive green roofs it has been argued present a:

...tremendous opportunity to retrofit and green existing structures in cities, thereby realizing multiple benefits of green roofs, including: reduced runoff and flood management; reducing energy demands in heating and cooling houses; improving the longevity and replacement costs of roofs; and benefiting city climate all while also providing for aesthetics and wildlife benefits in downtown areas. The latter includes ground nesting birds and various types of bees that feed on the nectar of blooming plants' (Tourbier [6]).

Pioneered in Germany extensive green roofs were made possible by the development of geofabrics and lightweight soils. Plants are essential elements in the functioning of green roofs because they intercept and delay rainfall runoff by holding precipitation in the plant foliage and absorbing water in the root zone causing an eventual reduction in total runoff by 50 percent or greater (Tourbier [6]). An extensive green roof typically has shallow soil $(50-150 \mathrm{~mm})$, is not irrigated, generally requires little maintenance, have limited plant diversity and limited or no access. Hardy, drought tolerant, low height plants are required in what is often a dry, hot and windy environment. They may provide green 'views' for occupants of adjacent rooms or buildings (Kwok and Grondzik [7]). Extensive green roofs can be retrofitted to existing buildings with a slope of up to 35 degrees, although roofs with a slope of over 20 degrees require a baffle to prevent soil slump.

An intensive green roof in contrast has deeper soil to support a larger variety of plants. Soil depths vary depending on the planting requirements - from 200300mm for lawn up to 1.5-1.8 meters for large trees (Kwok and Grondzik [7]). Intensive green roofs provide accessible open space and often include larger plants, food growing areas and trees as well as walkways, water features and irrigation systems. As a result intensive green roofs require high levels of maintenance and greater accessibility. Because of this difference specifications differ dramatically from extensive green roofs. Intensive green roofs are feasible only on flat roofed buildings and the added weight of soil and water requires a substantial building structure. They are therefore more costly but are more energy efficient than extensive green roofs and have the capacity for greater storm water retention. To protect plants and occupants in a usually high wind environment intensive green roofs require a windbreak and a railing or wall. Trees should also be anchored against wind. Green roofs tend to be labourintensive and require fertilization and irrigation (Tourbier [6]). The potentials for retrofitting existing buildings with intensive green roofs are limited.

Use of the terms 'intensive' or 'extensive' to describe green roofs has however been criticized because it is 'terminology' driven rather than use driven and can lead to confusion and inaccuracy in the design documentation and client 
expectations (Hopper [8]). The problem with the use of blanket terms, according to Weiler and Scholz-Barth [2] is that

...neither clearly reflects the system's expected purpose or use nor adequately conveys design or maintenance requirements. Furthermore, a terminology-driven, rather than use-driven, approach to the design and construction of green roofs can lead to additional confusion and inaccuracy in design, documentation, and client expectations.

What the authors are referring to is that rather than being simply 'green', green roofs serve a range of different purposes depending on design and client intent. What is significant here is the way in which the term 'green' dominates discussions around rooftop plantings and as a result assumptions are made about the benefits of all green roofs.

\section{Green or brown?}

In the literature the term intensive is often used to describe roof top gardens that are distinguished by alternative terms including 'Eco roofs', 'living roofs', nature roofs, 'brown' or biodiversity roofs, spontaneous green roofs, edible buildings, landscape over structure, elevated landscapes, cool roofs and blue roofs, and somewhat disparagingly 'sedum roofs' because of the dominance of sedum species in the construction of green roofs internationally. What all of these distinctions are alluding to is of course the purpose or intent of green roof construction in the first place because not all of them necessarily tick all of the sustainability, or even environmental 'boxes' in the same way. The distinctions reflect a broader debate within green roof discourse about whether all green roofs are, or should be 'green'. For instance, for Gedge [9], living roofs should reflect local places and so 'decisions shouldn't be made on the basis of horticulture but in relation to nature and the environment'. Such roofs may not be 'green', but are seen as a 'replacement for natural habitat'. Building on the work of Stephan Brenneisen in Switzerland in the 1990's, Gedge campaigned for the creation of biodiversity roofs in London for the black redstart and other wildlife as an alternative to the 'uniform swards of sedum' Grant [10]. Biodiversity roofs are topographically varied, include habitat features such as logs and are typically planted with wildflowers.

Within the Australian context Hopkins and Goodwin [4] coin the term 'bushtop' in an attempt to distinguish green roofs in the Australian context from other international examples. They define bushtop somewhat whimsically as referring to:

...the Australian bush or natural landscape that holds historic iconic status in the Australian psyche. Given that the great majority of the population lives in cities and are relatively isolated from the bush, the authors' concept of the bushtop is to transpose a little piece of the bush onto the tops of city buildings to help reconnect people with their cultural and environmental heritage. The difference between a bushtop landscape and a rooftop garden is that the bushtop is the integration of natural systems, plant communities, animals, birds and insects 
interacting with each other to survive and operate as an ecosystem,

whereas a rooftop garden is an ornamental horticultural display.

For these authors 'green' denotes an urban aesthetic that is not necessarily in keeping with the indigenous Australian landscape. This is more than just a matter of words and exchanging words. “Green' as metaphor denotes an urban aesthetic that reinforces a particular globalized way of seeing and thinking about what an urban landscape should 'look' like. In doing so, other 'brown' spaces are excluded from being worthy of consideration or value.

\section{Green or grey?}

Green roofs more generally are seen as an effort to 'green' the 'grey' landscape of cities in a period of rapid urbanization. Their importance has particular synergies in Australia, one of the most urbanized countries in the world with over $80 \%$ of the population living in urban areas in 2007. This figure is set to increase more rapidly in the coming decades. By 2050, Australia, New Zealand and Northern America are all expected to be over 90 per cent urban; a figure that is higher than anywhere else in the world (United Nations [11]). Therefore, managing the effects of urbanisation is considered to be one of the most urgent practical challenges of sustainability. Global sustainability is increasingly an issue of urban sustainability (Bugliarello [12]). Within this context the need for green roofs goes hand in hand with arguments to increase the density of cities globally as a way of mitigating the impact of urbanization and reducing urban 'sprawl'. However, one needs to ask why the focus on the 'greenness' of green roofs? The construction of green roofs is also closely connected to other key terms in the sustainability lexicon including liveability and resilience. 'Green' as a leitmotif or symbol for green roof raises a whole series of questions about what a green roof actually is and does. Does 'green' in fact denote 'sustainability'? Green as a descriptor overlooks the harshness of conditions on a rooftop in a temperate climate. Should plant selection always be based on 'greenness'? What is the connection between sustainability and green? And how relevant is the use of the term 'green' particularly in the Australian context? As Latz [13] has argued:

The topic of green roofs is closely connected to 'ecological correctness', and is part of the indemnification vocabulary of sins committed in bad conscious like landscape consumption and the displacement of nature.

What Latz is suggesting is that much of the rhetoric around green roofs is about language-in-use. Contained within the rhetoric is a future vision of what a city should look like. In this future 'green', 'liveable', resilient dense city public open space on the horizontal plane is at a premium and so, as the argument goes, elevating that space onto walls and rooftops of buildings will allow for increased densities to create a system of 3 dimensional green spaces in cities, without the loss of open space. In a simple rendition of the dominant sustainable city storyline Hopkins and Goodwin [4] express the benefits of green roofs as follows: 
This new urban form features higher densities, reduced private vehicle travel distances, promotion of public transport and reduction of the 'suburban sprawl'. This means that cities are becoming denser and the space between the built form is coming under pressure from competing activities, resulting in less open and green space in the public realm. One of the tools available to the urban designer or landscape architect for creating more open space and natural environment, as well as accommodating the other competing pressures for space, is to use the surfaces of the built form - the walls and rooftops of the buildings - to create a new open space using living walls and green roofs.

The unspoken question in all of this is of course, access. Defined as Landscape over structure or the integration of landscape and architecture green roofs are often seen as a replacement for 'green' space at ground level, a claim that is often couched in terms of adding to green spaces in cities. However, who lives or works in the buildings above the ground and who can occupy the space needs careful consideration. Or put another way if green spaces at ground level are replaced by elevated green space what are the socio-political consequences of this move?

Beyond questions around the 'social' sustainability of green roofs however, questions have also been raised about the economic sustainability of green roofs. As an example a 2006 study focusing on mitigation of New York's hear island effect (Rozenzweig et al. [14]) examined the impact of urban forestry, living (green) roofs and light roofs on the near surface temperatures and the heat island effect. The study developed nine mitigation scenarios within 6 case study areas in the city and evaluated each of the scenarios in terms of temperature reduction and cost effectiveness. Each of the scenarios was based on a combination of three key strategies - street plantings or urban forestry, green roofs or light roofs and while the study found that each of these strategies had an effect of temperature the study recommended that a '...combined strategy that maximizes the amount of vegetation in New York City by planting trees along streets and in open spaces, as well as by building living (or green) roofs (i.e. ecological infrastructure), offers more potential cooling than any individual strategy'. There were two significant determinants for this finding. Firstly, while land availability for street planting was considered a constraint for urban forestry, the cost of green roofs as compared to street plantings was considerable. The study found that implementation costs ranged from \$199 million for open space planting to $\$ 5,855$ million for living roofs. Significantly, the study noted that:

Of the three heat island mitigation strategies considered in this study, urban forestry, and particularly planting and kerbside street trees, contributes additional non-energy benefits such as fostering environmental equity in poorer neighbourhoods that tend to have hotter temperatures and fewer street trees, and bringing cooling benefits to areas where people live and work [14].

Within the Australian context, Williams et al. [15] have identified perceived cost as a significant barrier to adoption of green roofs and the development of incentive schemes. They point out that the dominant form of green roof in 
Australia currently is intensive involving higher maintenance costs and a lack of demonstration projects to inspire confidence. Other barriers identified by the authors include lack of an established green roof industry, lack of scientific data for evaluation, minimal inclusion in green star rating schemes and planning policies, plant selection, availability of substrate components and mixes, lack of Australian standards and guidelines, lack of experience and knowledge and questions around the use of potable water for irrigation. Despite these barriers to adoption the authors note that there is increasing interest in establishing green roofs in Australia.

\section{Green roofs in Melbourne}

The city of Melbourne is the capital city of Victoria, Australia. Green roofs in the city are a somewhat recent phenomenon when considered within the international context. Early examples include the Freshwater Place residential tower in Melbourne (2002) with its Level 10 rooftop Half Acre Garden and Melbourne City Council's CH2 building (2006) - Australia’s first 6-star Green Star Design commercial office. More recent examples include the Pixel building and The Venny a Children's Community Centre in Holland Park, Kensington with a 200sqm, extensive green roof. The Venny roof was developed as part of a 2-year research project with the University of Melbourne to gather information about green roofs in a Melbourne context. Since 2008, Melbourne City Council and influential business groups have become active promoting the benefits of green roofs. Growing Up: The Blueprint to Green Roof Melbourne” is one such program being run by the Committee for Melbourne and the city of Melbourne hosts Canopy - Melbourne's Green Roof Forum a quarterly discussion forum supported by Green Roofs Australia and Weblow a commercial mulching firm. The following discussion is based on a brief case study of five green roofs in the city of Melbourne that is part of a larger study that evaluated these projects using sustainability criteria (Table 1). Each of the five projects was evaluated against the key criteria with a focus on what evidence was available to establish the claim. Data was gathered using site visits and interviews. The discussion here focuses specifically on two key aspects of the evaluation concerned with design intent and access after proving a brief overview of key specification for the projects in Tables $2-5$.

While two of the projects, $\mathrm{CH} 2$ and the Pixel building share a similar intent the remaining three are quite different. In three of the green rooftops $(\mathrm{CH} 2$, the Venny and the Pixel building) plant health is periodically monitored by University of Melbourne researchers. One of the rooftops (Freshwater Place) required high levels of resource input and maintenance. All of the rooftops have limited access. In fact, each of the site visits access involved a complex process of appointments, tours and security. In the case of the Venny, the inclusion of the rooftop reflected the values of the place with no access to the rooftop other than for maintenance. In four of the five sites there were varying degrees of recreational space for occupants with no access for others. Visual access came from above. While for each of the sites there is some, often anecdotal, evidence 
of reduction in energy use and storm water flows the social benefits of green roofs are largely confined to existing occupants and again anecdotally include increased productivity and amenity. As a result claims to social sustainability remain tenuous.

In addition with the exception of the Hassell rooftop the other 4 rooftops were new constructions. This seems to reflect findings of a 2009 study in Melbourne by Wilkinson and Reed [16] that posed the question - Why are there not more green roofs on buildings in our city centre? The study analyzed 526 buildings in Melbourne CBD and found that 'a very small proportion of CBD stock in Melbourne is found to be suited. These buildings are most likely to be low secondary locations, ungraded or B grade buildings, privately owned, concrete framed and not overshadowed by adjoining Of the 526 buildings analysed 78 appeared to be suitable for green roof technology but given the type of buildings for most of these 78 buildings a retrofit seemed unlikely. The authors concluded that 'greater potential for green roof retrofit exists in the suburbs or regional towns where lower rise buildings may reduce the amount of overshadowing found in city centres (Wilkinson and Reed [16]).

Table 1: $\quad$ Sustainability criteria.

\begin{tabular}{|ll|}
\hline 1. & Environmental \\
\hline a. & Reduce heat island effect (reduce radiated heat from buildings) \\
\hline b. & Noise Reduction \\
\hline c. & Increase biodiversity: \\
& -plants \\
& -invertebrates \\
& -birds \\
& -mammals \\
\hline d. & Reduce storm water run-off contributing to:- \\
& - water quality \\
& -flood mitigation/ reduced run-off \\
\hline e. Improve air quality \\
\hline 2. & Economic \\
\hline a. & Reduce energy use in building \\
& -Heating \\
\hline b. & -Cooling \\
\hline c. & Increase roof longevity worker productivity \\
\hline d. & Increase property values \\
\hline e. & Job creation \\
\hline 3. & Social \\
\hline a. & Increase recreational use of space \\
\hline b. & Green relief \\
\hline c. & Increase food production in city \\
\hline d. & Increased amenity \\
\hline e. & Worker health \\
\hline & \\
\hline
\end{tabular}


Table 2: $\quad$ The Venny, Kensington.

\begin{tabular}{|l|l|}
\hline Location & JJ Holland Park, Kensington \\
\hline Type & Extensive, New construction, module based \\
\hline Access & Limited \\
\hline Area & $\begin{array}{l}\text { Lower Roof Area total: } 108 \mathrm{~m}^{2} \\
\text { East Zone: } 14.6 \mathrm{~m}^{2} \\
\text { West Zone: } 63 \mathrm{~m}^{2} \\
\text { South Zone: } 30.5 \mathrm{~m}^{2}\end{array}$ \\
\hline Pitch & Minimal gradient (1:100) \\
\hline Input/resources & Minimal \\
\hline Design Intent & $\begin{array}{l}\text { A communal backyard that provides facilities and programs for } \\
\text { disadvantaged young people in the Kensington area. The Green roof is } \\
\text { understood to reflect, even symbolize, the broader sustainability agenda } \\
\text { adopted at the centre. }\end{array}$ \\
\hline
\end{tabular}

\section{Table 3: $\quad$ Freshwater Place.}

\begin{tabular}{|l|l|}
\hline Location & $\begin{array}{l}\text { Queensbridge Square, Melbourne. The green roof is built on top of a 9 story } \\
\text { car park. }\end{array}$ \\
\hline Type & Intensive, new construction, in situ. \\
\hline Access & Residents and guests of residents only \\
\hline Area & $1650 \mathrm{~m}^{2}$ or half an acre \\
\hline Pitch & Minimal gradient (1:100) \\
\hline Input/resources & $\begin{array}{l}\text { The green roof is irrigated using water from a water storage tank } \\
\text { underneath. A wind break wall has been built as the roof suffers from high } \\
\text { wind exposure from the south. }\end{array}$ \\
\hline Design Intent & $\begin{array}{l}\text { Constructed as an elevated landscaped garden as part of residential lifestyle } \\
\text { facilities on level 10 - including a pool, sauna, gym, barbeque area, sauna } \\
\text { and home theatre. There are 540 apartments in the Freshwater Place tower. } \\
\text { Recently a small vegetable garden has been planted in crate boxes on a } \\
\text { small balcony on the west façade. }\end{array}$ \\
\hline
\end{tabular}

Table 4: $\quad$ The Pixel building.

\begin{tabular}{|l|l|}
\hline Location & Cnr Bouverie and Queensbury street, Melbourne. \\
\hline Type & Extensive, new construction, extensive, modular and in situ. \\
\hline Access & Building is currently vacant. Future access for office workers and guests. \\
\hline Area & $840 \mathrm{~m}^{2}$ \\
\hline Pitch & Minimal (1:100) \\
\hline Input/resources & $\begin{array}{l}\text { Regular weeding and monitoring of plant health. Maintenance by Melbourne } \\
\text { University, Burnley. }\end{array}$ \\
\hline Design Intent & $\begin{array}{l}\text { To achieve a } 6 \text { star Green building award and to create recreational space for } \\
\text { building occupants. }\end{array}$ \\
\hline
\end{tabular}

\section{Table 5: $\quad$ CH2: Council House.}

\begin{tabular}{|l|l|}
\hline Location & Little Collins st, Melbourne. \\
\hline Type & Extensive and Intensive. New Construction, module based. \\
\hline Access & Council staff and staff guests only. Online tours available. \\
\hline Area & - \\
\hline Pitch & minimal \\
\hline Input/resources & Irrigation \\
\hline Design Intent & Visual amenity, human comfort, research, part of 6 star green building rating. \\
\hline
\end{tabular}


Table 6: Hassell rooftop.

\begin{tabular}{|l|l|}
\hline Location & 61 Little Collins st, Melbourne. \\
\hline Type & Extensive, Retrofit, minimal planting. \\
\hline Access & Minimal. Staff and staff guests. \\
\hline Area & small \\
\hline Pitch & Minimal gradient (1:100) \\
\hline Input/resources & Minimal, hand watering of smart pots. \\
\hline Design Intent & A recreational space for staff. An event space. \\
\hline
\end{tabular}

\section{Conclusion}

What this brief survey begins to suggest is that despite the list of well-accepted and often-repeated benefits of green roofs, none of the rooftops surveyed met all of the sustainability claims that circulate in academic literature and the popular media. There is also a lack of data that supports the claims made by green roof enthusiasts and most of the data that does exist is derived from small 'test' plots rather than built projects and this is particularly true in the Australian context. As a result, reliable predictions of performance are 'difficult' (Snodgrass and McIntyre [17]).

What all of this suggests is that the design intent of any given green roof project should be at the forefront of sustainability claims. And while some 'green' roofs may indeed be green and others brown; rather than relying on generalized claims about the benefits, design intent needs to be stated from the outset. Otherwise discussions will remain terminology-driven rather than usedriven [2] and all green roof projects run the risk of being labelled as simply green branding. In addition without careful attention to questions of access the contribution that green roofs will make to 'sustainability' for ALL residents of a city is not guaranteed.

\section{References}

[1] Sassi, P. Strategies for Sustainable Architecture Taylor and Francis: Oxon, 2006.

[2] Weiler, S. and Scholz-Barth, K. Green Roof Systems: A Guide to the Planning, Design, and Construction of Landscapes over Structure John Wiley and Sons Inc: Hoboken, New Jersey, 2009.

[3] Beatley, T. Green Cities of Europe: Global Lessons on Green Urbanism Island Press: Washington DC, 2012.

[4] Hopkins, G and Goodwin, C. Living Architecture: Green Roofs and Walls CSIRO Publishing: Collingwood, Australia, 2011.

[5] Davis, M. Fortress Los Angeles: the Militarisation of Urban Space (Chapter 1) Variations on a Theme Park: The New American City and the End of Public Space ed. M. Sorkin. Hill and Wang: New York, pp 154-180, 1992. 
[6] Tourbier, J.T. Green Roofs, urban vegetation and urban runoff (chapter 44) The Routledge Handbook of Urban Ecology eds. I. Douglas, D. Goode, M. C. Houck and R. Wang Routledge: Oxon pp. 572-582, 2011.

[7] Kwok A.C. and Grondzik, W.T. The Green Studio Handbook: Environmental Strategies for Schematic Design, Second Edition, Elsevier: M.A. and Oxford. 2011.

[8] Hopper, L.J. Landscape Architectural Graphic Standards: Student Edition John Wiley and Sons: New Jersey, 2007.

[9] Gedge, D. Sustainable Entrepreneur, Green Futures Magazine, 9th October, 2006 http://www.forumforthefuture.org/greenfutures/articles/sustainableentrepreneur-0

[10] Grant, G Ecosystem Services Come to Town: Greening Cities by Working with Nature John Wiley and Sons: UK, 2012.

[11] United Nations Department of Economic and Social Affairs World Urbanization Prospects The 2007 Revision United Nations: New York, 2008. http://www.un.org/esa/population/publications/wup2007/2007WUP_ Highlights_web.pdf

[12] Bugliarello, G. 2006 Urban Sustainability: Dilemmas, Challenges and Paradigms’ Technology in Society Vol. 28, pp. 19-26.

[13] Latz, P. Introduction Green Roof-A Case Study: Michael Van Valkeenburgh Associates' Design for the Headquarters of the American Society of Landscape Architects ed. Christian Werthmann, Princeton Architectural Press: New York, pp 14-15, 2007.

[14] Rozenzweig, C. Solecki, W.D. and Slosberg, R.B. Mitigating New York City's Heat Island with Urban Forestry, Living Roofs, and Light Surfaces: New York City Regional Heat Island Initiative: Final Report 2006 http://www.fs.fed.us/ccrc/topics/urbanforests/docs/NYSERDA_heat_island. pdf

[15] Williams, N.S.G, Rayner, J.P and Raynor, K.J. Green roofs for a wide brown land: Opportunities and barriers for rooftop greening in Australia. Urban Forestry and Urban Greening 9, pp. 245-251, 2010.

[16] Wilkinson, S. J. and Reed, R. Green roof retrofit potential in the central business district, Property Management, 27 (5), pp.284 - 3012009.

[17] Snodgrass, E. C. and McIntyre, L. The Green Roof Manual: A Professional Guide to Design, Installation, and Maintenance, Timber Press: Portland, Oregon, 2010. 